\title{
PENDAMPINGAN KEGIATAN \\ PELATIHAN DESAIN GRAFIS UNTUK WARGA DESA CIPUTRI DI KECAMATAN KADUHEJO KABUPATEN PANDEGLANG
}

\author{
Usep Saepul Mustakim¹, Mohamad Sulaiman Suryanto², Minhatul Ma'arif ${ }^{3}$, Ratna Dewi", \\ Asep Saefullah Kamali ${ }^{5}$, Idris Supriadi ${ }^{6}$, Linda7, Badri Munawar ${ }^{8}$, Dede Imtihanudin ${ }^{9}$, Ira \\ Asyura9 ${ }^{9}$, Ade Juanto ${ }^{10}$
}

\author{
1-10Sekolah Tinggi Keguruan dan Ilmu Pendidikan Syekh Manshur \\ Alamat : Jalan Raya Labuan Km 5 Kadulisung Pandeglang \\ Email : usepsam@gmail.com
}

\begin{abstract}
Abstrak
Rendahnya kemampuan desain warga masyarakat di desa ciputri sangat dikamingkan padahal mereka adalah penerus untuk peradaban selanjutnya. Disamping itu warga desa ciputri belum ada lembaga kursus untuk pelatihan desain grafis, maka dari dasar itulah diadakannya pendampingan pada kegiatan pelatihan desain grafis selama sehari penuh. Tujuan dari kegiatan ini adalah meningkatkan kreatifitas warga masyarakat khususnya pemuda dan pelajar di desa ciputri kecamatan kaduhejo kabupaten pandeglang. Kegiatan ini diikuti sebanyak 35 orang dan diharapkan dapat membuat peserta menjadi mandiri sehingga dapat membuat desain seperti pamflet, banner atau spanduk sendiri dan tidak menggunakan jasa dari percetakan. Metode pelaksanaan konvensional digunakan dalam kegiatan pelatihan ini dengan penyampaian materi dan praktek secara langsung kepada santri dan pelajar. Melalui kegiatan ini peserta dapat mengenal desain grafis serta dapat mempraktekkan aplikasi yang digunakan untuk membuat desain grafis tersebut.
\end{abstract}

Kata Kunci : Pelatihan Desain Grafis, Warga Desa Ciputri

Abstract

The low design ability of the people in Ciputri village is very unfortunate even though they are the successors to the next civilization. Besides that, the residents of Ciputri village do not yet have a course institution for graphic design training, so from that basis, assistance is held on graphic design training activities for a full day. The purpose of this activity is to increase the creativity of community members, especially youth and students in Ciputri Village, Kaduhejo District, Pandeglang Regency. This activity was attended by 35 people and is expected to make participants become independent so that they can make designs such as pamphlets, banners or banners themselves and do not use the services of a printer. Conventional implementation methods are used in this training activity by delivering material and practice directly to students and students. Through this activity, participants can get to know graphic design and can practice the applications used to create the graphic design.

Keywords: Graphic Design Training, Ciputri Villagers

@UsepSaepul Mustakim.et.al

91|K A ib on A b hin a y a 


\section{PENDAHULUAN}

Minimnya kesadaran dalam belajar membuat warga masyarakat di Desa Ciputri tidak begitu tertarik dalam mempelajari desain grafis karena kondisi lingkungan sekitar yang memang kurang mendukung untuk belajar desain grafis. Perkembangan teknologi saat ini menuntut peningkatan keahlian yang dimiliki oleh kaum milenial pada dunia kerja. Salah satu keahlian yang dianjurkan untuk ditingkatkan oleh pada kaum milenial khususnya para santri dan pelajar adalah keahlian desain grafis. Desain grafis merupakan suatu bentuk komunikasi visual yang menggunakan gambar untuk menyampaikan informasi atau pesan seefektif mungkin. Dalam desain grafis, teks juga dianggap gambar karena merupakan hasil abstraksi simbol-simbol yang bisa dibunyikan.

Desain grafis adalah salah satu bentuk seni lukis (gambar) terapan yang memberikan kebebasan kepada sang desainer (perancang) untuk memilih, menciptakan, atau mengatur elemen rupa seperti ilustrasi, foto, tulisan, dan garis di atas suatu permukaan dengan tujuan untuk diproduksi dan dikomunikasikan sebagai sebuah pesan. Gambar maupun tanda yang digunakan bisa berupa tipografi atau media lainnya seperti gambar atau fotografi.

Desain grafis umumnya diterapkan dalam dunia periklanan, packaging, perfilman, dan lain-lain. Dengan kemampuan desain grafis yang dimiliki, santri dan pelajar juga dapat menciptakan suatu karya atau produk desain grafis dengan berbagai model dan bentuk, misalnya produk desain grafis yang terdapat di pasaran bebas, seperti kartu nama, leaflet, sampul CD, sampul kaset, desain kaos, sampul buku mata pelajaran, poster dan lain-lain.

Program pelatihan ini adalah hasil dari observasi yang dilakukan pada santri dan Sebagian pelajar yang berada di Kp. Balepunah. Menurut hasil observasi yang sdudah dilaksanakan, diselenggarakannya pelatihan ini di latarbelakangi oleh lemahnya kemampuan pelajar dan santri pada saat membuat pamflet, banner atau spanduk. Akibatnya mereka harus membayar jasa desain grafis untuk 1 kegiatan sekitar 50 - 100 ribu rupiah.

Dari permasalahan tersebut akhirnya kami memutuskan untuk membuat kegiatan pengabdian pada 
masyarakat yaitu "Pelatihan Desain Grafis Untuk Pelajar dan Santri" dengan adanya kegiatan ini diharapkan dapat meningkatkan kreatifitas pelajar dan santri dalam dunia design. Dan juga bisa membuatmereka mampu mandiri. Adapun kegiatan yang relevan dan pernah dilaksanakan yaitu kegiatan pelatihan komputer pada guru SD Ciruji 1 di Kecamatan Banjarsari pada tahun 2018.

\section{METODE PELAKSANAAN}

Pada program ini kami menargetkan untuk pelajar dan santri dimana di Kp. Balepunah ini menurut kami adalah kampung santri. Sebab di kampung ini pondok pesantren saling berdampingan. Awal untuk melakukan tahapan program ini kami bersilaturahmi dengan salah satu pondok yaitu Pondok Pesantren Tahfidzul Qur'an dimana dalam silaturahmi ini sekaligus meminta izin untuk menggunakan tempat mengadakan pelatihan ini.

Setelah mendapat izin kami membagikan informasi kepada pondok pondok sekitar melalui pengurus pengurus pondok sekitar. Pada tanggal 28 Agustus 2021 tepatnya hari sabtu kami melaksanakan pengabdian masyarakat di Pondok Pesantren Tahfidzul Qur'an.
Adapun manual kegiatannya dapat dilihat pada tabel berikut.

Tabel 1

Kegiatan Pelatihan Desain Grafis

\begin{tabular}{|c|c|}
\hline Waktu & Kegiatan \\
\hline $08.00-09.00$ & Pembukaan dan Motivasi \\
\hline $09.00-12.00$ & $\begin{array}{c}\text { Sesi I } \\
\text { Pengenalan Teknik Dasar } \\
\text { Menguasai Corel Draw }\end{array}$ \\
\hline $12.00-13.00$ & Jeda Istirahat \\
\hline $13.00-16.00$ & $\begin{array}{c}\text { Sesi II } \\
\text { Menjadi Desai Grafis } \\
\text { Profesional }\end{array}$ \\
\hline
\end{tabular}

Selama proses pelatihan design grafis yang kami lakukan, kami melihat Sebagian besar masih buta tentang dunia design dan belum mengenal aplikasi untuk membuat design baik itu di laptop ataupun di Handphone. Dari peserta yang hadir hanya ada 1 peserta yang sudah mengetahui tentang design.

\section{HASIL DAN PEMBAHASAN}

Kegiatan pengabdian kepada masyarakat ini dilakukan dengan metode presentasi tentang materi pelatihan, kemudian peserta langsung mempraktekkan pada komputer masingmasing dan peserta dapat bertanya jika menghadapi kendala dalam pengerjaan.

Hasil kegiatan pengabdian kepada masyarakat ini menunjukkan bahwa peserta mendapatkan pengetahuan dalam 
pembuatan desain grafis serta mendapatkan pengalaman dalam membuat desain flyer, banner dan spanduk. Kegiatan pengabdian kepada masyarakat ini diikuti oleh 35 orang peserta. 27 diantaranya santri dan 8 seorang pelajar, dan dilaksanakan dalam 2 sesi.

Dalam kegiatan pengabdian kepada masyarakat ini peserta sangat antusias dalam mengikuti. Untuk mengukur sejauh mana tingkat keberhasilan kegiatan yang dilaksanakan, maka digunakan kuesioner yang disebar kepada para peserta pelatihan.

Dasar penilaian yang dilakukan mengunakan 4 kriteria yaitu: tidak bagus, kurang bagus, bagus, dan cukup bagus. Adapun untuk klasifikasi penilaiannya dapat dilihat pada tabel berikut.

Tabel 2

Kriteria Penilaian Desain Grafis

\begin{tabular}{|c|c|c|}
\hline Kriteria & Nilai & Unsur \\
\hline $\begin{array}{c}\text { Sangat } \\
\text { Bagus }\end{array}$ & 4 & $\begin{array}{c}\text { Rapi, Detail, Teliti dan } \\
\text { Bermakna }\end{array}$ \\
\hline Bagus & 3 & $\begin{array}{c}\text { Rapi, Detail, Teliti Belum } \\
\text { Bermakna }\end{array}$ \\
\hline $\begin{array}{c}\text { Cukup } \\
\text { Bagus }\end{array}$ & 2 & $\begin{array}{c}\text { Rapi dan Detail Belum Teliti } \\
\text { dan } \\
\text { Bermakna }\end{array}$ \\
\hline $\begin{array}{c}\text { Kurang } \\
\text { Bagus }\end{array}$ & 1 & $\begin{array}{c}\text { Rapi Kurang Detail, Teliti dan } \\
\text { Bermakna }\end{array}$ \\
\hline
\end{tabular}

Berdasarkan hasil kuesioner yang diisi oleh 35 peserta, disajikan pada grafik dibawah ini.

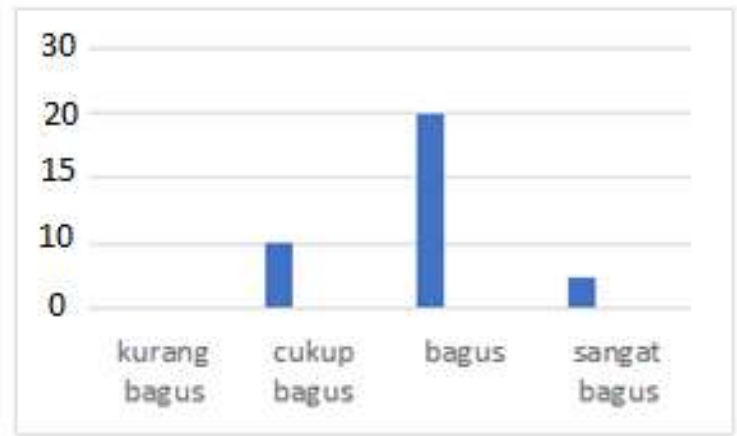

Gambar 1. Grafik Hasil Koesioner

Hasil evaluasi kegiatan Berdasarkan hasil penilaian pada grafik diatas terkait dengan materi yang disampaikan dan pelatihan yang telah dilakukan, bahwa kegiatan Pengabdian pada Masyarakat ini dapat meningkatkan kemampuan peserta dalam bidang desain grafis. Hal ini terlihat dari total 35 peserta yang memberikan penilaian bahwa (20 orang) dinyatakan bagus , 10 orang dinyatakan cukup bagus dan 5 orang dinyatakan sangat bagus.

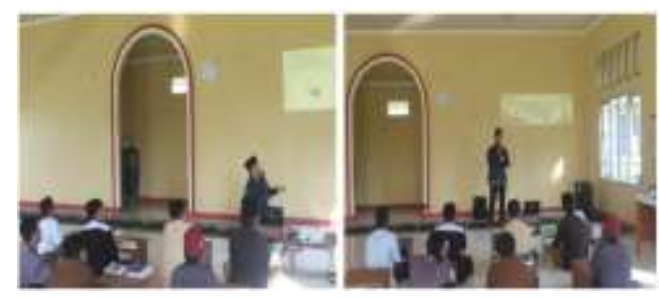

$$
\text { Gambar 2. Pemaparan Materi }
$$

\section{KESIMPULAN DAN SARAN}

Kegiatan pengabdian pada masyarakat yang telah dilakukan pada pelajar dan santri yang berada di Kp. Balepunah dapat memingkatkan 
kemampuan peserta dalam hal peningkatan kemampuan desain grafis. Hal ini dibuktikan dengan hasil penilaian peserta secara keseluruhan terhadap materi pelatihan yang diberikan cukup baik. Sehingga dapat disimpulkan bahwa peserta memiliki respon yang baik terhadap kegiatan pelatihan yang dilaksanakan pada kegiatan pengabdian pada masyarakat ini.

\section{UCAPAN TERIMAKASIH}

Tim pengabdian kepada masyarakat pada kesempatan ini menyampaikan ucapan terima kasih kepada Allah Subhanahu Wata'ala yang telah memberikan kemudahan untuk kami dalam melaksanakan program ini. Terimakasih juga untuk kedua orang tua yang senantiasa mendoakan kami, terimakasih juga kami ucapkan untuk Pondok pesantren tahfidzul Qur'an Kp. Balepunah yang telah bersedia menyediakan tempat untuk melaksanakan program ini. Dan tak lupa juga ucapan terimakasih kepada STKIP Syekh Manshur yang telah melaksanakan Kegiatan KKN Tematik Mandiri sehingga dengan adanya kegiatan tersebut kami bisa melaksanakan program ini dengan baik.

\section{DAFTAR PUSTAKA}

Dimyati dan Mudjiono. Belajar dan Pembelajar. Jakarta : Rineka Cipta, 2009
Hamalik, O. Proses Belajar Mengajar. Jakarta: Bumi Aksara, 2009

$\begin{array}{lrr}\text { Kemenkes } & \text { RI } & \text { Nomor } \\ \text { HK.01.07/MENKES/413/2020 } & \text { tentang } \\ \text { Pedoman } & \text { Pencegahan } & \text { dan } \\ \text { Pengendalian } & \text { Coronavirus } & \text { Disease } \\ 2019 \text { (Covid-19). } & & \end{array}$

Kamus Besar Bahasa Inggris (Online). Tersedia di http//www.kbbi.kemdikbud.go.id

Diakses 15 Agustus 2021

Kompri. Motivasi Pembelajaran. Bandung: Remaja Rosdakarya. 2015

Peraturan Menteri Kesehatan Nomor 382 tahun 2020 Tentang Protokoler Kesehatan

Sitepu, V. (2004). Panduan mengenal desain grafis. : www.escaeva.com

Sugiyono. Metode Penelitian Pendidikan Pendekatan Kuantitatif, Kualitatif Dan RED. Bandung: Alfabeta. 2011

UU no. 20 Tahun 2003 Tentang Sisdiknas Pasal 1 Ayat 20

Widya, L. A. D., \& Darmawan, A. J. (2016). Pengantar desain grafis : Direktorat Pembinaan Kursus dan Pelatih. 